and before the Middle and Upper; and a paragraph to this effect was inserted in the Introduction to the Crag Mollusca Supplement by Mr. Harmer and myself, which is published in the volume of the Palæontographical Society for 1871.

"With reference to the observation that all the great features of the country had come into existence before the Glacial period, I have already explained that several years ago I saw, and stated, that such of those great features as are connected with the curvilinear escarpments were of pre-glacial origin. What $I$ have long contended for against the general opinion of geologists, and still contend for, is that such of these great features as are connected with the rectilinear escarpments and ridges of the south and south-east of England, as e.g. those of the Isles of Wight and Purbeck, and of the Portsdown and Hogsback hills, are not of pre-glacial origin; but that they originated at the close of the Glacial period, or rather at what $I$ call earliest post-glacial, i.e. at the commencement of the emergence, as explained at page 21 of my paper in the Quarterly Journal, read Nov. 9, 1870.

"It would, I think, save mueh misapprehension and confusion, both now and in future, if you could manage to have this letter of explanation inserted at the end of your paper (if it is printed), and before the report of the discussion upon it. Searles V. Wood, Jun.

"W. H. Penning, Esq."

\title{
GLACIAL ORIGIN OF LAKE-BASINS.
}

SIR,-It appears to me that stratigraphical evidence can most successfully dispute the verdict of "not proven" brought by $\mathrm{Mr}$. Judd against Prof. Ramsay's theory of the glacial origin " of certain lakes." That subsidences of the crust can produce rock-basins is affirmed both by historical and geological evidence; but if the basins chance to lie among strata so regular and well exposed that the fact of subsidence could not have failed to record itself, and if the outcrops on the contrary tell only of erosion, theories of subsidence are fairly out of court; and it remains only to fix on the erosive agent.

The outcrop of the Carboniferous rocks of West Northumberland is so marked and regular, that on the Ordnance one-inch map the shading is disposed in bars alternately dark and light, representing linear escarpments with their interspaces; and among these, which may be said to dip at from $6^{\circ}$ to $12^{\circ}$, and are clearly pre-glacial, lie rock-basins known as the "Northumberlandlakes." Obviously, if these were occasioned by localized subsidence, deviation from the average line of strike must have ensued in the beds, while concentrated erosion would leave an excavated outcrop not attended by any such change. By careful and repeated observations, I find the latter to be the case. Tracing the scarped outcrop towards the water, those on the dipward side of the basin are scooped back into a crescentic curve, those more central to it being obliterated altogether. No facts can be more certain than that (1) subsidence would have altered the dip appreciably, and that (2) it has not done so; but by simply projecting 
the embayed outcrops abreast of the features on either hand, the basin is filled up, and the pre-existent surface approximately restored.

I believe that these are not isolated cases of rock-basins demonstrably eroded. Semerwater, in Yorkshire, which may be considered as an ontlier of the Lake District proper, is seemingly bounded by strata nearly horizontal and obviously undisturbed, and might well form a link between the small Northumberland lakes and those larger basins of the origin of which no stratigraphical evidence seems obtainable.

The comparative infrequence of sharp synclinals even in some rocks of great age seems to militate strongly against the subsidence theory of lakes. The extraordinary regularity of the Cambrian Sandstones of the western districts of Ross and Sutherland I believe to be quite irreconcilable with the great numbers of rock-basins in these regions on any theory save that of erosion. From Suilven more than 200 lakes and tarns can be counted, yet the present surface is but one of many that may have existed during the progress of that denudation of which Mr. Judd's Scottish researches so eloquently tell. If the movements in the crust had been half as rife in past geological ages as Mr. Judd's views of lake formation require for the recent one, the Cambrians could scarcely have shown a uniform dip for ten yards together.

In conclusion, rock basins I believe may be ranged under three heads. 1. Those demonstrably due to subterranean movements. 2. Those demonstrably due to erosion. 3. A large number of which the origin is, and in some cases may always remain, doubtful.

WARK-ON-TYNE, May 6 th, 1876 .

Hugh Miller,

H.M. Geol. Survey of England and Wales.

\section{OLDEST FOSSILIFEROUS ROCKS OF NORTHERN EUROPE.}

Sir,-In a letter inserted in the May Number of the Geological MLagazine, Mr. Hicks makes some objections to my paper on the Oldest Fossiliferous Rocks of Northern Europe in the April Number. There are especially two points in which Mr. Hicks thinks that my views are incorrect and endeavours to corroborate his own.

Firstly, Mr. Hicks attempts to demonstrate that the Swedish area cannot have heen depressed at as early a period as the British, by reasoning as follows: The Cambrian and Lower Silurian rocks of Sweden have an average thickness of $1000 \mathrm{ft}$., while the British are $30,000 \mathrm{ft}$. in thickness; there is no reason why the Swedish area should not have been depressed at the same rate as the British; the lowest Swedish beds must, therefore, be younger than the lowest British, for, if that be not the case, we must suppose that before the close of the Lower Silurian period the Swedish sediments were deposited in a depth of $29,000 \mathrm{ft}$. of water, which is impossible, as the characters of the faunas indicate very similar conditions in the British and Swedish areas. If we draw the full logical consequences of this Mr. Hicks' reasoning, we come of necessity to the conclusion that all the strata which we have in Sweden been used to refer 